\title{
EVALUASI STATUS KERUSAKAN TANAH UNTUK PRODUKSI BIOMASSA DI DESA NGLEGI, KECAMATAN PATUK, KABUPATEN GUNUNGKIDUL
}

\author{
SOIL DAMAGE STATUS EVALUATION FOR BIOMASS PRODUCTION \\ IN NGLEGI VILLAGE, PATUK SUBDISTRICT, GUNUNGKIDUL DISTRICT
}

\author{
Rachmad Fajar Wibisono ${ }^{1)}$, AZ Purwono Budi Santoso ${ }^{2) *}$, dan Dyah Arbiwati ${ }^{2)}$ \\ ${ }^{1)}$ Prodi Agroteknologi, Universitas Pembangunan Nasional Veteran Yogyakarta \\ 2) Prodi Ilmu Tanah, Universitas Pembangunan Nasional Veteran Yogyakarta \\ ${ }^{*}$ Corresponding author E-mail: pbudisant@yahoo.com
}

\begin{abstract}
Soil is a factor of biomass production that supports human life and other living things that must be preserved and maintained. On the other, uncontrolled biomass production activities can cause soil damage, which can reduce the quality and function, which in turn can threaten the survival of humans and other living things. Nglegi village has a hilly topography with a relatively slope level $8 \%$ - > $40 \%$ which causes erosion to occur frequently in this area. So that information is needed regarding the status of soil damage so that in the efforts of land users it can be done well to support biomass production activities, especially in agriculture. The purpose of the research was to determine the status of soil damage for biomass production and compile a land damage status map in Nglegi Village, Patuk Sub-district, Gunungkidul Regency. This research used survey methods to know general condition of area and the research location was determined purposively. Determine of sample points based on land unit map which was made by overlaying the soil type map, land use map and slope map. The results showed that the Nglegi Village was classified into two classes of damage status, namely the status of lightly damage (R.I) with an area of about 372.98 ha or $40.07 \%$ of the total area of Nglegi village. The status of damage is not damaged $(\mathrm{N})$ with an area of 557.82 ha or $59.93 \%$ of the total area of Nglegi Village. Lightly damage status (R.I) with permeability and redox limiting factors.
\end{abstract}

Keywords: biomass, evaluation, soil damage status

\begin{abstract}
ABSTRAK
Tanah merupakan faktor produksi biomassa yang mendukung kehidupan manusia serta makhluk hidup lainnya yang harus dijaga dan dipelihara kelestariannya. Di sisi lain, kegiatan produksi biomassa yang tidak terkendali dapat mengakibatkan kerusakan tanah, sehingga dapat menurunkan kualitas dan fungsinya, yang pada akhirnya dapat mengancam kelangsungan hidup manusia dan makhluk hidup lainnya. Desa Nglegi memiliki topografi perbukitan dengan tingkat kemiringan lereng tergolong cukup curam dengan tingkat kemiringan 8\% - >40\% menyebabkan erosi sering terjadi di daerah ini. Sehingga diperlukan informasi mengenai status kerusakan tanah sehingga dalam upaya pemanfaat lahan dapat dilakukan dengan baik untuk menunjang kegiatan produksi biomassa khususnya dalam bidang pertanian. Tujuan dari penelitian adalah menentukan status kerusakan tanah untuk produksi biomassa dan menyusun peta status kerusakan tanah untuk produksi biomassa di Desa Nglegi, Kecamatan Patuk, Kabupaten Gunungkidul. Metode yang dilakukan dalam penelitian ini terdiri dari pengamatan (survey) untuk mengetahui kondisi umum daerah penelitian dan lokasi penelitian ditentukan secara purposif. Penentuan titik sampel berdasarkan Satuan Peta Lahan hasil dari overlay peta jenis tanah, peta tataguna lahan dan peta kemiringan lereng. Hasil Penelitian menunjukkan Desa Nglegi tergolong dalam dua kelas status
\end{abstract}


kerusakan yaitu status kerusakan rusak ringan (R.I) dengan luas sekitar 372,98 ha atau 40,07\% dari keseluruhan luas desa Nglegi. Status kerusakan tidak rusak (N) dengan luas 557,82 ha atau $59,93 \%$ dari keseluruhan luas wilayah Desa Nglegi. Status rusak ringan (R.I) dengan faktor pembatas permeabilitas dan redoks.

\section{Kata kunci: biomassa, evaluasi, status kerusakan tanah}

\section{PENDAHULUAN}

Tanah merupakan faktor produksi biomassa yang mendukung kehidupan manusia serta makhluk hidup lainnya yang harus dijaga dan dipelihara kelestariannya. Perkembangan ilmu pengetahuan dan teknologi yang pesat telah menempatkan biomassa sebagai sumber energi terbarukan yang ramah lingkungan. Di sisi lain, kegiatan produksi biomassa yang tidak terkendali dapat mengakibatkan kerusakan tanah, sehingga dapat menurunkan kualitas dan fungsinya, yang pada akhirnya dapat mengancam kelangsungan hidup manusia dan makhluk hidup lainnya.

Gunungkidul dikenal sebagai daerah yang kekurangan air, karena sebagian besar sumber air (sungai) terletak di bawah tanah (underground river) berdaya dukung rendah. Salah satu wilayah tersebut adalah Desa Nglegi, Kecamatan Patuk, keadaan alam ini menyebabkan sebagian besar penduduknya merupakan petani lahan kering. Selain itu, Desa Nglegi memiliki topografi perbukitan dengan tingkat kemiringan lereng tergolong cukup curam (8\% - >40\%) menyebabkan erosi sering terjadi di daerah ini. Menurut Rencana Pembangunan Jangka Menengah Daerah Kabupaten Gunungkidul 2016-2021 wilayah Nglegi dikategorikan pada kawasan rawan longsor.

Dalam upaya mencegah dan mengendalikan kerusakan tanah, pemerintah Indonesia mengeluarkan Peraturan Pemerintah Republik Indonesia Nomor 150 Tahun 2000 tentang Pengendalian Kerusakan Tanah untuk Produksi Biomassa. Peraturan tersebut digunakan sebagai pedoman dalam penyusunan peta kerusakan tanah yang digunakan sebagai acuan dalam kegiatan pencegahan dan pengendalian kerusakan tanah untuk produksi biomassa. Dengan adanya penelitian evaluasi status kerusakan tanah untuk produksi biomassa dapat memberikan informasi tentang status kerusakan yang terjadi di wilayah tersebut.

\section{METODE PENELITIAN}

Penelitian dan pengamatan lapangan dilaksanakan pada bulan November 2018 di Desa Nglegi, Kecamatan Patuk, Kabupaten Gunungkidul. Metode yang dilakukan dalam penelitian ini terdiri dari pengamatan (survey) untuk mengetahui kondisi umum daerah penelitian dan wilayah sekitar lokasi penelitian. Penentuan lokasi penelitian dilakukan secara purposif. Satuan Peta Lahan (SPL) yang dibuat berdasarkan hasil tumpang susun (overlay) dari peta tataguna lahan, kemiringan lereng dan jenis tanah. Titik pengambilan sampel ditentukan berdasarkan 8 Satuan Peta Lahan (SPL) yang telah dibuat, jumlah sampel yang diambil sebanyak 20 titik secara random sampling. Analisis laboratorium dilaksanakan di laboratorium Ilmu Tanah, laboratorium Biologi Tanah Universitas Pembangunan Nasional "Veteran" Yogyakarta dan Laboratorium Tanah, Tanaman, Pupuk dan Air Balai Pengkajian Teknologi Pertanian (BPTP) Yogyakarta.

Penentuan status kerusakan tanah menggunakan Indikator Penentuan Kriteria Baku Kerusakan Tanah Untuk Produksi Biomassa menurut PP No 150 Tahun 2000. 
Tabel 1. Indikator Penentuan Kriteria Baku Kerusakan Tanah Untuk Produksi Biomassa menurut PP No 150 Tahun 2000.

\begin{tabular}{|c|c|c|c|c|}
\hline No & Parameter & Ambang Kritis & Metode Pengukuran & Peralatan \\
\hline 1 & Ketebalan solum & $<20 \mathrm{~cm}$ & Pengukuran langsung & Meteran \\
\hline 2 & $\begin{array}{l}\text { Kebatuan } \\
\text { permukaan }\end{array}$ & $>40 \%$ & $\begin{array}{c}\text { Pengukuran langsung } \\
\text { imbangan batu dan } \\
\text { tanah dalam unit } \\
\text { luasan }\end{array}$ & $\begin{array}{l}\text { Meteran; counter } \\
\text { (line atau total) }\end{array}$ \\
\hline 3 & Komposisi Fraksi & $\begin{array}{c}<18 \% \text { koloid } \\
>80 \% \text { pasir } \\
\text { kuarsatik }\end{array}$ & $\begin{array}{l}\text { Warna pasir, } \\
\text { gravimetrik }\end{array}$ & $\begin{array}{l}\text { Tabungukur; } \\
\text { timbangan }\end{array}$ \\
\hline 4 & Berat isi & $>1,4 \mathrm{~g} / \mathrm{cm}^{3}$ & $\begin{array}{l}\text { Gravimetrik pada } \\
\text { satuan volume }\end{array}$ & $\begin{array}{l}\text { Lilin. Tabung ukur, } \\
\text { ring sample, } \\
\text { timbangan analitik }\end{array}$ \\
\hline 5 & Porositas total & $<30 \% ;>70 \%$ & $\begin{array}{c}\text { Perhitungan BV dan } \\
\text { BJ }\end{array}$ & $\begin{array}{c}\text { Piknometer, } \\
\text { timbangan analitik }\end{array}$ \\
\hline 6 & $\begin{array}{c}\text { Derajat pelulusan } \\
\text { air }\end{array}$ & $\begin{array}{l}<0,7 \mathrm{~cm} / \mathrm{jam} \\
>0,8 \mathrm{~cm} / \mathrm{jam}\end{array}$ & Permeabilitas & $\begin{array}{c}\text { Ring sample, } \\
\text { double ring } \\
\text { permeameter }\end{array}$ \\
\hline 7 & $\mathrm{pH}\left(\mathrm{H}_{2} \mathrm{O}\right) 1: 2,5$ & $<4,5:>8,5$ & Potensiometrik & $\begin{array}{l}\mathrm{pH} \text { meter, } \mathrm{pH} \text { stick } \\
\text { skala } 0,5 \text { satuan }\end{array}$ \\
\hline 8 & $\begin{array}{l}\text { Daya hantar } \\
\text { listrik }\end{array}$ & $>4,5 \mathrm{mS} / \mathrm{cm}$ & Tahanan listrik & EC meter \\
\hline 9 & Redoks & $<200 \mathrm{mV}$ & Tegangan listrik & $\begin{array}{l}\text { pH meter, } \\
\text { elektroda platina }\end{array}$ \\
\hline 10 & Jumlah mikroba & $<10^{2} \mathrm{cfu} / \mathrm{g}$ tanah & Planting technique & $\begin{array}{l}\text { Cawan petri, } \\
\text { colony counter }\end{array}$ \\
\hline
\end{tabular}

\section{HASIL DAN PEMBAHASAN}

Penentuan status kerusakan tanah untuk produksi biomassa berdasarkan Peraturan Menteri Lingkungan Hidup (2009) melalui dua tahapan yaitu matching dan skoring dengan mengacu pada kriteria baku kerusakan tanah yang telah di tetapkan pemerintah di dalam Peraturan Pemerintah Nomor 150 tahun 2000. Data hasil analisis dilakukan matching membandingkan antara data parameter-parameter kerusakan tanah yang terukur dengan kriteria baku kerusakan tanah (PP No. 150 tahun 2000). Matching ini dilakukan pada setiap titik pengamatan. Dengan metode ini, setiap titik pengamatan dapat dikelompokan ke dalam tanah yang tergolong rusak $(\mathrm{R})$ atau tidak rusak $(\mathrm{N})$.

Metode skoring dilakukan dengan mempertimbangkan frekuensi relatif kerusakan tanah yang tergolong rusak dalam suatu poligon. Yang dimaksud dengan frekuensi relatif kerusakan tanah adalah nilai persentase kerusakan tanah didasarkan perbandingan jumlah contoh tanah yang tergolong rusak yaitu hasil pengukuran setiap parameter kerusakan tanah yang sesuai dengan kriteria baku kerusakan tanah, terhadap jumlah keseluruhan titik pengamatan yang dilakukan dalam poligon tersebut. Hasil penilaian status kerusakan tanah tersaji pada tabel - tabel berikut: 
Tabel 2. Penilaian Status Kerusakan Tanah untuk Produksi Biomassa.

\begin{tabular}{|c|c|c|c|c|c|c|c|c|c|c|c|c|c|c|c|}
\hline \multirow{3}{*}{\multicolumn{2}{|c|}{ Parameter }} & \multirow{3}{*}{ simbol } & \multirow{3}{*}{ Ambang Kritis } & \multicolumn{12}{|c|}{ Satuan peta lahan } \\
\hline & & & & \multicolumn{4}{|c|}{1 (Semak belukar 8-15\%) } & \multicolumn{4}{|c|}{ 2(Semak belukar $15-25 \%$ ) } & \multicolumn{4}{|c|}{3 (Kebun campuran $15-25 \%)$} \\
\hline & & & & T1 & T2 & FR (\%) & SFR & T3 & T4 & FR (\%) & SFR & T5 & T18 & FR (\%) & SFR \\
\hline Ketebalar & solum $(\mathrm{cm})$ & $s$ & $<20$ & 60 & 50 & 0 & 0 & 40 & 80 & 0 & 0 & $>100$ & $>100$ & 0 & 0 \\
\hline Kebatuan & ermukaan $(\%)$ & $\mathrm{b}$ & $>40$ & $<5$ & $<5$ & 0 & 0 & $<5$ & $<5$ & 0 & 0 & $<5$ & $<10$ & 0 & 0 \\
\hline \multirow{3}{*}{$\begin{array}{l}\text { Komposisi } \\
\text { fraksi }\end{array}$} & Pasir (\%) & \multirow{3}{*}{ f } & \multirow{3}{*}{$\begin{array}{l}<18 \% \text { koloid, } \\
>80 \% \text { pasir }\end{array}$} & 20 & 23 & 0 & 0 & 25 & 11 & 0 & 0 & 3 & 12 & 0 & 0 \\
\hline & Debu $(\%)$ & & & 46 & 41 & 0 & 0 & 31 & 53 & 0 & 0 & 51 & 47 & 0 & 0 \\
\hline & Lempung (\%) & & & 34 & 36 & 0 & 0 & 44 & 36 & 0 & 0 & 46 & 41 & 0 & 0 \\
\hline \multicolumn{2}{|c|}{$\mathrm{BV}\left(\mathrm{g} / \mathrm{cm}^{3}\right)$} & $\mathrm{d}$ & $>1,4$ & 0,99 & 1,10 & 0 & 0 & 0,92 & 1,07 & 0 & 0 & 1,15 & 1,13 & 0 & 0 \\
\hline \multicolumn{2}{|c|}{ Porositas (\%) } & $\mathrm{n}$ & $<30,>70$ & 56,75 & 53,83 & 0 & 0 & 57,92 & 51,91 & 0 & 0 & 51,39 & 52,91 & 0 & 0 \\
\hline \multicolumn{2}{|c|}{ Permeabilitas (cm jam) } & p & $<0,7,>8,0$ & 7 & 2 & 0 & 0 & 5 & 7 & 0 & 0 & 9 & 2 & 50 & 2 \\
\hline \multicolumn{2}{|c|}{$\mathrm{pH}$} & a & $<4,5 ;>8,5$ & 7,53 & 7,51 & 0 & 0 & 7,29 & 8,08 & 0 & 0 & 7,98 & 7,86 & 0 & 0 \\
\hline \multicolumn{2}{|c|}{$\mathrm{DHL}(\mathrm{mS} / \mathrm{cm})$} & $\mathrm{e}$ & $>4,5$ & 0,142 & 0,025 & 0 & 0 & 0,033 & 0,160 & 0 & 0 & 0,140 & 0,165 & 0 & 0 \\
\hline \multicolumn{2}{|c|}{ Redoks (mV) } & $\mathrm{r}$ & $<200$ & 302 & 196 & 50 & 2 & 261 & 264 & 0 & 0 & 253 & 264 & 0 & 0 \\
\hline \multicolumn{2}{|c|}{ Jumlah Mikroba $\left(10^{5} \mathrm{cfu} / \mathrm{g}\right)$} & $\mathrm{m}$ & $<10^{2}$ & 11,7 & 9,5 & 0 & 0 & 10,8 & 8,1 & 0 & 0 & 12,7 & 8,8 & 0 & 0 \\
\hline & ah skor & & & & & & 2 & & & & 0 & & & & 2 \\
\hline \multicolumn{4}{|c|}{ Status kerusakan } & \multicolumn{4}{|c|}{$\begin{array}{c}\text { R.I - r } \\
\text { (rusak ringan, redoks) }\end{array}$} & \multicolumn{4}{|c|}{ N (tidak rusak) } & \multicolumn{4}{|c|}{$\begin{array}{l}\text { R.I-p (rusak ringan, } \\
\text { permeabilitas) }\end{array}$} \\
\hline
\end{tabular}

Keterangan

$\mathrm{FR}=$ Frekuensi relatif

SFR $=$ Skor frekuensi relatif

T1-T20 $=$ Titik sampel

Tabel 3. Penilaian Status Kerusakan Tanah untuk Produksi Biomassa (lanjutan).

\begin{tabular}{|c|c|c|c|c|c|c|c|c|c|c|c|c|c|c|c|c|c|}
\hline \multirow{3}{*}{\multicolumn{2}{|c|}{ Parameter }} & \multirow{3}{*}{ Simbol } & \multirow{3}{*}{ Ambang Kritis } & \multicolumn{14}{|c|}{ Satuan peta lahan } \\
\hline & & & & \multicolumn{5}{|c|}{4 (Kebun campuran $8-15 \%)$} & \multicolumn{4}{|c|}{$5($ Sawah $8-15 \%)$} & \multicolumn{5}{|c|}{6 (Kebun campuran $25-40 \%$ ) } \\
\hline & & & & T6 & T7 & T17 & $\begin{array}{l}\text { FR } \\
(\%)\end{array}$ & SFR & T8 & T19 & $\begin{array}{l}\text { FR } \\
(\%)\end{array}$ & SFR & T9 & T11 & $\mathrm{T} 12$ & $\begin{array}{l}\mathrm{FR} \\
(\%)\end{array}$ & SFR \\
\hline Ketebalan & olum $(\mathrm{cm})$ & 3 & $<20$ & $>100$ & 60 & 60 & 0 & 0 & 60 & 80 & 0 & 0 & $>100$ & $>100$ & 80 & 0 & 0 \\
\hline Kebatuan p & mukaan $(\%)$ & $\mathrm{b}$ & $>40$ & $<5$ & $<5$ & $<10$ & 0 & 0 & $<5$ & $<5$ & 0 & 0 & $<5$ & $<10$ & $<5$ & 0 & 0 \\
\hline \multirow{3}{*}{$\begin{array}{l}\text { Komposisi } \\
\text { fraksi }\end{array}$} & Pasir $(\%)$ & \multirow{3}{*}{ f } & \multirow{3}{*}{$\begin{array}{l}<18 \% \text { koloid, } \\
>80 \% \text { pasir }\end{array}$} & 1 & 6 & 37 & 0 & 0 & 4 & 7 & 0 & 0 & 12 & 29 & 6 & 0 & 0 \\
\hline & Debu $(\%)$ & & & 27 & 29 & 36 & 0 & 0 & 29 & 24 & 0 & 0 & 39 & 30 & 51 & 0 & 0 \\
\hline & $\begin{array}{l}\text { Lempung } \\
(\%)\end{array}$ & & & 72 & 65 & 27 & 0 & 0 & 67 & 69 & 0 & 0 & 49 & 41 & 43 & 0 & 0 \\
\hline \multicolumn{2}{|c|}{$\mathrm{BV}\left(\mathrm{g} / \mathrm{cm}^{3}\right)$} & d & $>1,4$ & 1,22 & 1,17 & 1,04 & 0 & 0 & 1,20 & 1,21 & 0 & 0 & 1,13 & 1,11 & 1,14 & 0 & 0 \\
\hline \multicolumn{2}{|c|}{ Porositas (\%) } & n & $<30,>70$ & 54,60 & 53,77 & 57,80 & 0 & 0 & 54,68 & 52,17 & 0 & 0 & 52,49 & 47,47 & 57,60 & 0 & 0 \\
\hline \multicolumn{2}{|c|}{ Permeabilitas (cm jam) } & $p$ & $<0,7,>8,0$ & 6 & 3 & 10 & 33,3 & 2 & 4 & 4 & 0 & 0 & 4 & 4 & 6 & 0 & 0 \\
\hline \multicolumn{2}{|c|}{$\mathrm{pH}$} & a & 4,$5 ;>8,5$ & 6,85 & 6,00 & 6,23 & 0 & 0 & 6,00 & 5,84 & 0 & 0 & 6,45 & 6,47 & 5,87 & 0 & 0 \\
\hline \multicolumn{2}{|c|}{$\mathrm{DHL}(\mathrm{mS} / \mathrm{cm})$} & e & $>4,5$ & 0,031 & 0,028 & 0,052 & 0 & 0 & 0,034 & 0,027 & 0 & 0 & 0,036 & 0,032 & 0,021 & 0 & 0 \\
\hline \multicolumn{2}{|c|}{ Redoks (mV) } & 1 & $<200$ & 256 & 267 & 270 & 0 & 0 & 244 & 248 & 0 & 0 & 294 & 242 & 228 & 0 & 0 \\
\hline \multicolumn{2}{|c|}{$\begin{array}{l}\text { Jumlah Mikroba }\left(10^{3}\right. \\
\text { cfu/g) }\end{array}$} & $\mathrm{m}$ & $<10^{2}$ & 5,7 & 5,8 & 12,5 & 0 & 0 & 5,0 & 9,6 & 0 & 0 & 4,3 & 9,8 & 6,6 & 0 & 0 \\
\hline Juml & h skor & & & & & & & 2 & & & & 0 & & & & & 0 \\
\hline \multicolumn{4}{|c|}{ Status kerusakan } & \multicolumn{5}{|c|}{$\begin{array}{c}\text { R.I - p } \\
\text { (rusak ringan,permeabilitas) }\end{array}$} & \multicolumn{4}{|c|}{$\mathrm{N}$ (tidak rusak) } & \multicolumn{5}{|c|}{$\mathrm{N}$ (tidak rusak) } \\
\hline \multicolumn{18}{|c|}{$\begin{array}{l}\text { Keterangan : } \\
\text { FR }=\text { Frekuensi relatif } \\
\text { SFR }=\text { Skor frekuensi relatif } \\
\text { T1-T20 }=\text { Titik sampel }\end{array}$} \\
\hline
\end{tabular}

Meningkatnya intensitas penggunaan lahan berdampak pada kerusakan tanah, manajemen pengelolaan tanah memiliki peran dalam mengurangi dampak kerusakan tanah. Melihat kondisi kerusakan tanah di Desa Nglegi, status kerusakannya termasuk dalam kategori tidak rusak $(\mathrm{N})$ dan rusak ringan (R.I). Pada kategori rusak ringan (R.I) yang menjadi faktor pembatas yaitu permeabilitas dan redoks. Permeabilitas sangat dipengaruhi oleh tekstur, struktur dan porositas tanah. Pada tanah yang didominasi dengan partikel kasar atau pasiran, maka akan mempunyai tingkat permeabilitas yang sangat cepat. Sedangkan pada tanah yang didominasi partikel halus akan berpengaruh pada tingkat permeabilitas tanah yang lambat. Faktor pembatas laju permeabilitas terdapat pada satuan peta lahan 3,4 dan 7 yang tergolong agak cepat dengan laju permeabilitas masing-masing $9 \mathrm{~cm} / \mathrm{jam}, 10 \mathrm{~cm} / \mathrm{jam}$ dan $9 \mathrm{~cm} / \mathrm{jam}$. 
Tabel 4. Penilaian Status Kerusakan Tanah untuk Produksi Biomassa (lanjutan).

\begin{tabular}{|c|c|c|c|c|c|c|c|c|c|c|c|c|c|}
\hline \multirow{3}{*}{\multicolumn{2}{|c|}{ Parameter }} & \multirow{3}{*}{ Simbol } & \multirow{3}{*}{$\begin{array}{l}\text { Ambang } \\
\text { Kritis }\end{array}$} & \multicolumn{10}{|c|}{ Satuan peta lahan } \\
\hline & & & & \multicolumn{5}{|c|}{7 (Kebun campuran $>40 \%)$} & \multicolumn{5}{|c|}{8 (Tegalan ladang $25-40 \%)$} \\
\hline & & & & $\mathrm{T} 10$ & $\mathrm{~T} 13$ & $\mathrm{~T} 20$ & $\begin{array}{l}\text { FR } \\
(\%)\end{array}$ & SFR & $\mathrm{T} 14$ & $\mathrm{~T} 15$ & T16 & $\begin{array}{l}\text { FR } \\
(\%)\end{array}$ & SFR \\
\hline Ketebalar & solum $(\mathrm{cm})$ & $s$ & $<20$ & $>100$ & 80 & 50 & 0 & 0 & 80 & 60 & 60 & 0 & 0 \\
\hline Kebatuan & ermukaan (\%) & $\mathrm{b}$ & $>40$ & $<10$ & $<5$ & $<10$ & 0 & 0 & $<10$ & 25 & $<10$ & 0 & 0 \\
\hline \multirow{3}{*}{$\begin{array}{l}\text { Komposisi } \\
\text { fraksi }\end{array}$} & Pasir (\%) & \multirow{3}{*}{$\mathrm{f}$} & \multirow{3}{*}{$\begin{array}{c}<18 \% \\
\text { koloid, } \\
80 \% \text { pasir }\end{array}$} & 2 & 16 & 28 & 0 & 0 & 11 & 13 & 18 & 0 & 0 \\
\hline & Debu (\%) & & & 60 & 43 & 38 & 0 & 0 & 39 & 36 & 36 & 0 & 0 \\
\hline & Lempung (\%) & & & 38 & 41 & 34 & 0 & 0 & 50 & 51 & 46 & 0 & 0 \\
\hline \multicolumn{2}{|c|}{$\mathrm{BV}\left(\mathrm{g} / \mathrm{cm}^{3}\right)$} & $\mathrm{d}$ & $>1,4$ & 1,18 & 1,10 & 1,21 & 0 & 0 & 1,23 & 1,21 & 1,14 & 0 & 0 \\
\hline \multicolumn{2}{|c|}{ Porositas (\%) } & $n$ & $<30,>70$ & 50,11 & 53,03 & 52,17 & 0 & 0 & 45,98 & 48,90 & 55,26 & 0 & 0 \\
\hline \multicolumn{2}{|c|}{ Permeabilitas (cmjam) } & $p$ & $<0,7,>8,0$ & 9 & 2 & 4 & 33,3 & 2 & 4 & 5 & 2 & 0 & 0 \\
\hline \multicolumn{2}{|c|}{$\mathrm{pH}$} & a & $<4,5 ;>8,5$ & 6,40 & 6,73 & 6,69 & 0 & 0 & 5,62 & 5,41 & 5,54 & 0 & 0 \\
\hline \multicolumn{2}{|c|}{$\mathrm{DHL}(\mathrm{mS} / \mathrm{cm})$} & $\mathrm{e}$ & $>4,5$ & 0,026 & 0,030 & 0,027 & 0 & 0 & 0,021 & 0,048 & 0,026 & 0 & 0 \\
\hline \multicolumn{2}{|c|}{ Redoks (mV) } & 1 & $<200$ & 270 & 262 & 255 & 0 & 0 & 256 & 285 & 289 & 0 & 0 \\
\hline \multirow{2}{*}{\multicolumn{2}{|c|}{$\begin{array}{c}\text { Jumlah Mikroba }\left(10^{5} \mathrm{cfu} / \mathrm{g}\right) \\
\text { Jumlah skor }\end{array}$}} & $\mathrm{m}$ & $<10^{2}$ & 7,8 & 8,5 & 19,8 & 0 & 0 & 9,7 & 5,8 & 8,3 & 0 & 0 \\
\hline & & & & & & & & 2 & & & & & 0 \\
\hline \multicolumn{4}{|c|}{ Status kerusakan } & \multicolumn{5}{|c|}{$\begin{array}{c}\text { R.I }-\mathrm{p} \\
\text { (rusak ringan,permeabilitas) }\end{array}$} & \multicolumn{5}{|c|}{$\mathrm{N}$ (tidak rusak) } \\
\hline \multicolumn{14}{|c|}{$\begin{array}{l}\text { Keterangan : } \\
\begin{array}{l}\text { FR }=\text { Frekuensi relatif } \\
\text { SFR }=\text { Skor frekuensi relatif } \\
\text { T1-T20 = Titik sampel }\end{array}\end{array}$} \\
\hline
\end{tabular}

Tabel 5. Kelas laju permeabilitas.

\begin{tabular}{cccc}
\hline No & $\begin{array}{c}\text { Titik } \\
\text { Sample }\end{array}$ & $\begin{array}{c}\text { Permeabilitas } \\
(\mathbf{c m} / \mathbf{j a m})\end{array}$ & Kelas laju permeabilitas (Rayes, 2007) \\
\hline 1 & T1 & 7 & Agak cepat \\
2 & T2 & 2 & Agak lambat \\
3 & T3 & 5 & Sedang \\
4 & T4 & 7 & Agak cepat \\
5 & T5 & 9 & Agak cepat \\
6 & T6 & 6 & Agak cepat \\
7 & T7 & 3 & Sedang \\
8 & T8 & 4 & Sedang \\
9 & T9 & 4 & Sedang \\
10 & T10 & 9 & Agak cepat \\
11 & T11 & 4 & Agak sedang \\
12 & T12 & 6 & Agak cepat \\
13 & T13 & 2 & Agak lambat \\
14 & T14 & 4 & Sedang \\
15 & T15 & 5 & Sedang \\
16 & T16 & 2 & Agak lambat \\
17 & T17 & 10 & Agak cepat \\
18 & T18 & 2 & Agak lambat \\
19 & T19 & 4 & Sedang \\
20 & T20 & 4 & Sedang \\
\hline
\end{tabular}

Keterangan: $\mathrm{T} 1-\mathrm{T} 20=$ Lokasi pengambilan sample. 
PETA STATUS KERUSAKAN TANAH UNTUK PRODUKSI BIOMASSA DESA NGLEGI, KECAMATAN PATUK, KABUPATEN GUNUNGKIDUL

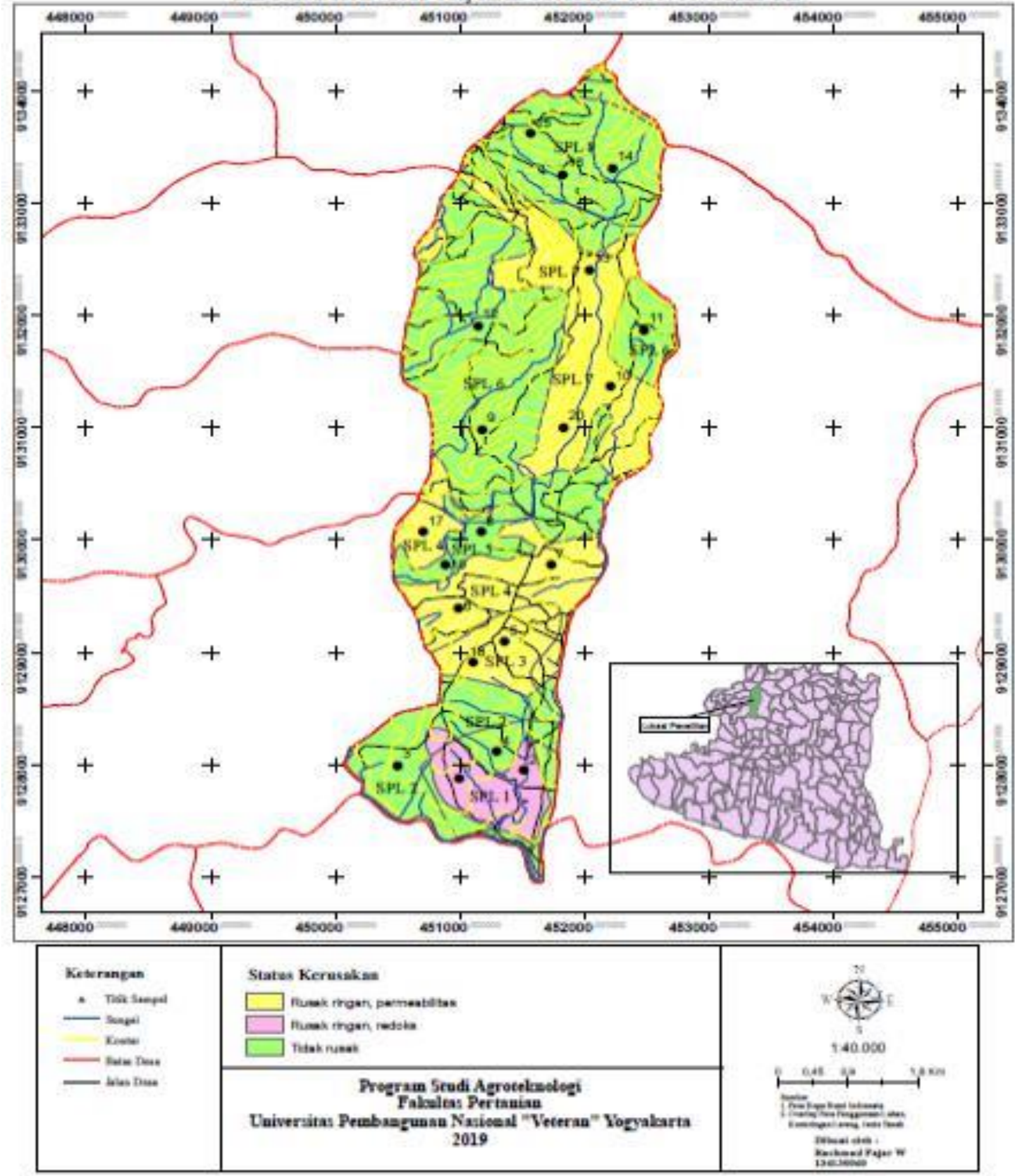

Gambar 1. Peta status kerusakan lahan 
Perbaikan dapat dilakukan dengan penambahan bahan organik yang berfungsi memperbaiki struktur tanah dengan pembentukan agregat tanah dan tidak melakukan pengolahan tanah yang terlalu intensif karena dapat merusak struktur tanah sehingga dapat mempercepat laju permeabilitas. Nilai potensial redoks yang tingi biasanya terjadi pada tanah yang mempunyai aerasi baik dan lebih banyak oksigen dalam larutan tanah sehingga makin banyak senyawa yang teroksidasi. Redoks potensial rendah terjadi pada tanah yang kahat atau kekurangan oksigen sehinga banyak senyawa yang tereduksi. Hasil evaluasi status kerusakan tanah di lokasi penelitian menunjukkan terdapat 2 status kerusakan tanah dengan faktor pembatas yang berbeda. Status kerusakan tanah rusak ringan (R.I.) terjadi pada satuan peta lahan 1, 3, 4 dan 7.

Pada satuan peta lahan 1 yang menjadi faktor pembatas dari kerusakan tanah adalah nilai redoks yang di bawah nilai ambang kritis $(<200 \mathrm{mV})$ yaitu sebesar $196 \mathrm{mV}$. Hasil tersebut berada pada lokasi titik sampel 2 pemanfaatan lahan semak/belukar dengan tingkat kemiringan $8 \%$ - 15\% dan memiliki kelas laju permeabilitas agak lambat $2 \mathrm{~cm} / \mathrm{jam}$ yang menyebabkan rendahnya nilai redoks. Rendahnya nilai redoks disebabkan karena kurangnya suplai $\mathrm{O} 2$ (oksigen) dalam tanah (reduksi). Kondisi tersebut dapat terjadi apabila ketika terjadi curah hujan tinggi yang menyebabkan terjadinya penjenuhan air di dalam tanah sehingga menurunkan kadar O2 tanah. Secara tidak langsung nilai redoks dapat mempengaruhi jumlah populasi mikroba di dalam tanah khususnya mikroba aerob yang membutuhkan $\mathrm{O} 2$ dalam proses perombakan bahan organik tanah. Mikroorganisme tanah memiliki peran penting terhadap ketersediaan unsur hara di dalam tanah selain melalui perombakan bahan organik tanah beberapa mikroorganisme mampu melakukan mineralilasi unsur hara di dalam tanah dari tidak tersedia menjadi tersedia bagi tanaman. Jumlah populasi mikro organisme tanah sering dijadikan indikator tingkat kesuburan tanah. Akan tetapi mikroorganisme membutuhkan lingkungan hidup yang sesuai dan mendukung seperti pada kisaran $\mathrm{pH}$ netral, ketersediaan oksigen yang cukup. Upaya perbaikan yang dapat dilakukan yaitu perbaikan drainase tanah dan aerasi tanah dengan pengolahan tanah, pembentukan saluran drainase penting untuk lokasi dengan laju permeabilitas rendah agar tidak terjadi genangan pada lahan yang relatif datar. Upaya lain yang dapat dilakukan untuk mengurangi kerusakan akibat nilai redoks yaitu dengan penambahan organik.

Penambahkan bahan organik melalui pemupukan ke dalam tanah sehingga kerusakan secara sifat fisik, sifat kimia dan sifat biologi dapat berkurang secara berkala (Reditya, et al. 2016). Peranan bahan organik terhadap kesuburan tanah antara lain; (1) mineralisasi bahan organik akan melepas unsur hara tanaman secara lengkap $(\mathrm{N}, \mathrm{P}, \mathrm{K}$, $\mathrm{Ca}, \mathrm{Mg}, \mathrm{S}$ dan unsur hara mikro lainnya) tetapi dalam jumlah yang relatif kecil, (2) meningkatkan daya menahan air, sehingga kemampuan tanah untuk menyediakan air menjadi lebih banyak, (3) memperbaiki kehidupan mikroorganisme tanah (Afandi, et al. 2015). Sedangkan untuk satuan peta lahan 2, 5, 6 dan 8 tidak mengalami kerusakan (N). Pada satuan peta lahan tersebut nilai dari masing-masing parameter tidak melebihi ketentuan ambang kritis yang telah di tetapkan. Pengelolaan tanah dilakukan secara baik seperti pembentukan teras-teras pada bagian lereng, dilakukannya penambahan kapur dan bahan organik tanah untuk meningkatkan $\mathrm{pH}$ pada tanah Latosol di lokasi penelitian untuk menunjang produksi biomassa. Luas wilayah dengan status kerusakan rusak ringan sekitar 372,98 ha atau 40,07\% dari keseluruhan luas desa Nglegi. Luas wilayah dengan status tidak mengalami kerusakan $(\mathrm{N})$ seluas 557,82 ha atau 59,93\% dari keseluruhan luas wilayah Desa Nglegi. 
Ketebalan solum merupakan jarak vertikal dari permukaan tanah sampai ke lapisan yang membatasi keleluasaan perkembangan sistem perakaran. Lapisan pembatas dapat berupa lapisan padas keras atau padas rapuh. Ketebalan solum berpengaruh terhadap pertumbuhan dan perkembangan akar tanaman. Data lapangan menunjukkan kedalaman solum di desa Nglegi berkisar antara $40 \mathrm{~cm}->100 \mathrm{~cm}$. Nilai tersebut diatas ambang kritis dari ketentuan penilaian status kerusakan tanah untuk produksi biomassa. Hal ini dipengaruhi oleh jenis tanah yang terdapat di daerah tersebut yaitu Latosol tanah yang mulai berkembang tetapi belum matang ditandai dengan perkembangan profil yang lebih lemah (Rachim dan Suwardi, 1999). Sebagian besar pemanfaatan lahan pada bagian lereng telah di bentuk teras-teras bangku sehingga dapat menjaga ketebalan solum tanah dan mengurangi tingkat bahaya erosi seperti pada satuan peta lahan 7 pemanfaatan lahan untuk kebun campuran dengan tingkat kemiringan lereng $>40 \%$ ketebalan solum pada bagian lereng mencapai $>100 \mathrm{~cm}$. Pemilihan vegetasi tanaman tahunan pada satuan peta lahan 7 dapat menurunkan tingkat bahaya erosi karena memiliki perakaran yang dalam dan tajuk tanaman dapat mengurangi kekuatan air hujan yang dapat mengakibatkan erosi.

Kebatuan permukaan pengamatan di lapangan menunjukkan presentase batuan $<10$ $\%$ jauh di bawah nilai ambang kritis dalam penilaian status kerusakan. Kebatuan permukaan berkaitan erat dengan komposisi fraksi dimana fraksi tanah di lokasi penilitian didominasi oleh fraksi debu, lempung dan sedikit mengandung fraksi pasir dapat dilihat pada Tabel 6.

Tabel 6. Kelas tekstur tanah menurut USDA.

\begin{tabular}{cccccc}
\hline \multirow{2}{*}{ No } & Titik & \multicolumn{3}{c}{ Fraksi } & \multirow{2}{*}{ Kelas Tekstur (USDA) } \\
\cline { 3 - 5 } & Sample & Pasir (\%) & Debu (\%) & Lempung (\%) & \\
\hline 1 & T1 & 20 & 46 & 34 & Geluh lempung debuan \\
2 & T2 & 23 & 41 & 36 & Geluh lempungan \\
3 & T3 & 25 & 31 & 44 & Lempung \\
4 & T4 & 11 & 53 & 36 & Geluh debuan \\
5 & T5 & 3 & 51 & 46 & Lempung Debuan \\
6 & T6 & 1 & 27 & 72 & Lempung \\
7 & T7 & 6 & 29 & 65 & Lempung \\
8 & T8 & 4 & 29 & 67 & Lempung \\
9 & T9 & 12 & 39 & 49 & Lempung debuan \\
10 & T10 & 2 & 60 & 38 & Geluh lempung debuan \\
11 & T11 & 29 & 41 & 30 & Geluh lempung \\
12 & T12 & 6 & 51 & 43 & Lempung debuan \\
13 & T13 & 16 & 43 & 41 & Lempung debuan \\
14 & T14 & 11 & 39 & 50 & Lempung \\
15 & T15 & 13 & 36 & 51 & Lempung \\
16 & T16 & 18 & 36 & 46 & Lempung \\
17 & T17 & 37 & 36 & 27 & Geluh \\
18 & T18 & 12 & 47 & 41 & Lempung debian \\
19 & T19 & 7 & 24 & 69 & Lempung \\
20 & T20 & 28 & 38 & 34 & Geluh Lempungan \\
\hline K &
\end{tabular}

Keterangan: T1 - T20 = Lokasi pengambilan sample

Tekstur tanah menunjukkan komposisi penyusun tanah yang dinyatakan sebagai perbandingan proporsi relatif antara fraksi pasir (sand), debu (silt) dan lempung (clay) Tekstur tanah merupakan karakteristik tanah yang penting dan berhubungan dengan sifat 
fisik maupun sifat kimia tanah dan secara tidak langsung mempunyai pengaruh terhadap tanaman (Hanafiah, 2013).

Peranan tekstur tanah dipengaruhi oleh perbandingan berat dari masing - masing fraksi, terutama fraksi lempung serta jenis mineral lempungnya. Tekstur tanah turut menentukan tata air dan udara dalam tanah serta kemampuan penetrasi akar ke dalam tanah. Tanah yang didominasi fraksi pasir akan banyak mempunyai pori-pori makro, fraksi debu akan membentuk pori-pori meso dan fraksi lempung akan membentuk poripori mikro. Berdasarkan hasil analisis laboratorium diketahui komposisi fraksi dan kelas tekstur disajikan dalam Tabel 6. Lokasi penelitian menunjukkan kelas tekstur geluh hingga lempung. Untuk kelas tekstur geluh merupakan kelas tekstur yang ideal untuk perakaran tanaman. Berat Volume (BV) tanah di desa Nglegi berkisar antara $0,99 \mathrm{~g} / \mathrm{cm}^{3}$ sampai $1,23 \mathrm{~g} / \mathrm{cm}^{3}$ untuk ambang kritis dari nilai BV adalah $>1,4 \mathrm{~g} / \mathrm{cm}^{3}$. Semakin tinggi nilai BV maka tanah akan semakin mampat (Prasetyo dan Thohiron, 2013). Pada lokasi penelitian nilai BV cukup baik untuk pertumbuhan tanaman karena tanah tidak terlalu mampat hal ini berpengaruh terhadap porositas tanah di lokasi penelitian berkisar antara 45,98 \% - 57,92 \%. Hasil tersebut tidak melampaui ambang kritis yaitu <30\% - >70\%. Porositas tanah pada lokasi penelitian cukup menyediakan ruang untuk berkembangnya perakaran tanaman sehingga menunjang untuk produktivitas biomassa. Apabila nilai BV terlalu tinggi $\left(>1,4 \mathrm{~g} / \mathrm{cm}^{3}\right)$ dapat dilakukan perbaikan dengan olah tanah dan penambahan bahan organik untuk menambah ruang pori pada tanah.

Tabel 7. Hasil analisis $\mathrm{pH}\left(\mathrm{H}_{2} \mathrm{O}\right)$ tanah.

\begin{tabular}{cccc}
\hline No & $\begin{array}{c}\text { Titik } \\
\text { Sample }\end{array}$ & pH H $\mathbf{~ O}$ & Harkat (Afany, 2000) \\
\hline 1 & T1 & 7.53 & Netral \\
2 & T2 & 7.51 & Netral \\
3 & T3 & 7.29 & Netral \\
4 & T4 & 8.08 & Agak alkalis \\
5 & T5 & 7.98 & Agak alkalis \\
6 & T6 & 6.85 & Netral \\
7 & T7 & 6.00 & Agak masam \\
8 & T8 & 6.00 & Agak masam \\
9 & T9 & 6.45 & Agak masam \\
10 & T10 & 6.40 & Agak masam \\
11 & T11 & 6.47 & Agak masam \\
12 & T12 & 5.87 & Agak masam \\
13 & T13 & 6.73 & Netral \\
14 & T14 & 5.62 & Agak masam \\
15 & T15 & 5.41 & Masam \\
16 & T16 & 5.54 & Masam \\
17 & T17 & 6.23 & Agak masam \\
18 & T18 & 7.86 & Agak alkalis \\
19 & T19 & 5.84 & Agak masam \\
20 & T20 & 6.69 & Netral \\
\hline \multicolumn{5}{c}{ Keterangan: T1 - T20 Lokasi pengambilan sample } \\
\multicolumn{5}{c}{} \\
\end{tabular}


Hasil analisis laboratorium untuk nilai $\mathrm{pH}$ tanah berkisar antara 5,41 - 8,08 ini menunjukkan pada lokasi peneletian telah dilakukan pengolahan tanah dengan menambahkan kapur sehingga $\mathrm{pH}$ pada Latosol meningkat terjadi pada Satuan Peta Lahan (SPL) 3. Nilai pH tidak melebihi ambang kritis penentuan status kerusakan sehingga untuk parameter $\mathrm{pH}$ tidak terjadi kerusakan.

Potensial hidrogen $(\mathrm{pH})$ tanah merupakan tingkat kemasaman tanah yang dicerminkan oleh konsentrasi ion $\mathrm{H}^{+}$dalam tanah. Nilai ambang kritis dalam penentuan status kerusakan tanah pada lahan kering apabila $\mathrm{pH}$ tanah berkisar antara $<4,5$ atau $>$ 8,5. $\mathrm{pH}$ tanah sangat mempengaruhi ketersediaan unsur hara makro maupun unsur hara mikro. Hanafiah (2013) menjelaskan bahwa pH optimum yang mendukung untuk ketersediaan hara tanah pada kisaran $\mathrm{pH}$ 7. Akan tetapi setiap tanaman memerlukan jumlah hara yang berbeda-beda, pengetahuan tentang pengaruh $\mathrm{pH}$ terhadap pola ketersediaan hara tanah dapat digunakan sebagai acuan dalam pemilihan tanaman yang sesuai pada suatu jenis tanah. Pada tanah Latosol sumber utama ion $\mathrm{H}^{+}$adalah hidrolisis Al sehingga menghasilkan $\mathrm{pH}$ rendah antara $4-5,5$. Sedangkan untuk tanah yang banyak mengandung pirit $\left(\mathrm{FeS}_{2}\right)$ dan sulfida $\left(\mathrm{H}_{2} \mathrm{~S}\right)$ hasil pereduksi bakteri sulfur akan stabil pada kondisi tergenang (anaerob) sedangkan apabila pada kondisi aerob (teroksidasi) dapat menghasilkan asam sulfat dan terjadi penurunan $\mathrm{pH}$ yang sangat rendah (Hanafiah, 2013).

\section{KESIMPULAN}

1. Berdasarkan analisis status kerusakan tanah untuk produksi biomassa di lahan kering menurut Peraturan Pemerintah No 150 Tahun 2000 bahwa Desa Nglegi tergolong dalam dua kelas status kerusakan yaitu status kerusakan ringan (R.I) pada satuan peta lahan (SPL) 1, 3, 4 dan 7 dengan luas 372,98 ha atau 40,07\% dari keseluruhan luas desa Nglegi. Status kerusakan tidak rusak (N) pada satuan peta lahan (SPL) 2, 5, 6 dan 8 seluas 557,82 ha atau 59,93\% dari keseluruhan luas wilayah Desa Nglegi.

2. Status rusak ringan R.I dengan faktor permbatas permeabilitas terjadi pada satuan peta lahan 3, 4 dan 7 dengan luasan mencapai 320,21 ha. Status kerusakan ringan dengan faktor pembatas redoks terjadi pada satuan peta lahan 1 dengan luas 52,77 ha.

\section{DAFTAR PUSTAKA}

Afandi, F. N., Siswanto, B., dan Nuraini, Y. 2015. Pengaruh Pemberian Berbagai Jenis Bahan Organik Terhadap Sifat Kimia Tanah pada Pertumbuhan Dan Produksi Tanaman Ubi Jalar di Entisol Ngrangkahan Pawon, Kediri. Jurnal Tanah dan Sumberdaya Lahan. Vol 2 No.2: 237-224

Afany, M. R. 2000. Analisis KimiawiTanah Prinsip Kerja dan Interpretasi. Jurusan Ilmu Tanah,Fakultas Pertanian, UPN Veteran Yogyakarta.

Arsyad, S. 2006. Konservasi Tanah dan Air. IPB Press. Bogor

Hanafiah, K. A. 2013. Dasar-Dasar Ilmu Tanah. Rajawali Press cetakan ke enam. Jakarta. Kementrian Negara Lingkungan Hidup Republik Indonesia. 2009. Pedoman Teknis Penyusunan Peta Status Kerusakan Tanah untuk Produksi Biomassa. Jakarta.

Pemerintah Kabupaten Gunungkidul, 2016. Rencana Pembangunan Jangka Menengah Daerah Tahun 2016-2021 Kabupaten Gunungkidul. Halaman 15.

Peraturan Pemerintah Nomor 150 Tahun 2000 Tentang Pengendalian Kerusakan Tanah 
untuk Produksi Biomassa.

Prasetyo dan Thohiron. 2012. Aplikasi SIG dalam Penilaian Status Kerusakan Tanah Untuk Produksi Biomassa di Kabupaten Tuban Jawa Timur. J-PAL, Vol. 4, No. 1. Universitas Brawijaya.

Reditya, B. A. S., Suyarto, R., dan Kesumadewi. 2016. Kajian Status Kerusakan Tanah pada Lahan Pertanian di Kecamatan Denpasar. E-Jurnal Agroteknologi Tropika. ISSN: 2301-6515 Vol.5 No.1

Rayes, M.L.2007. Metode Inventarisasi Sumber Daya Lahan. Andi Offset. Yogyakarta 